Original Article

\title{
Inhibitory activity of fermentation filtrate of red passion fruit pulp (Passiflora edulis sims.) against Escherichia coli extended-spectrum beta-lactamase (ESBL) and methicillin resistant Staphylococcus aureus (MRSA)
}

\author{
Iif Hanifa Nurrosyidah ${ }^{1,3}$, Ni Made Mertaniasih ${ }^{2}$ Isnaeni $^{1^{*}}$ \\ ${ }^{1}$ Department of Pharmaceutical Chemistry, Universitas Airlangga, Mulyorejo, Surabaya 60115, Indonesia \\ ${ }^{2}$ Department of Microbiology, Faculty of Medicine, Universitas Airlangga, Tambaksari, Surabaya 60268, Indonesia \\ ${ }^{3}$ Doctoral Program of Pharmacy, Faculty of Pharmacy, Universitas Airlangga, Mulyorejo, Surabaya 60115, Indonesia
}

\begin{abstract}
This study aims to determine the minimum inhibitory concentration (MIC) and bactericidal concentration (MBC) of the fermentation filtrate (FF) on red passion fruit pulp (Passiflora edulis Sims.) against Escherichia coli Extended Spectrum Beta Lactamase (ESBL) and Methicillin Resistant Staphylococcus aureus (MRSA). The method used was the fermentation of red passion fruit pulp for 24 h using De Man Rogosa Sharpe Broth (MRSbroth) media, and the result showed that the $\mathrm{FF}$ of red passion fruit pulp made a dilution series concentration of $50 \%, 25 \%$, $12.5 \%, 6.25 \%$. Considering this result, the MIC FF of red passion fruit cells against ESBL and MRSA has a 25\% dilution concentration, while MBC has a 50\% dilution concentration. This shows that red passion fruit has the potential to be developed as antibacterial material, especially to fight bacteria that are already resistant.
\end{abstract}

Keywords: Inhibitory, red passion fruit, fermentation filtrate, ESBL, MRSA

Received: 21 August 2020 Revised: 19 November 2020 Accepted: 27 November 2020

\section{Introduction}

Infectious diseases are still a major health problem in developing tropical countries like Indonesia, and death caused by infectious diseases is about $51 \%$ (Sardjono and Le, 2007). Many bacteria are resistant to some antibiotics, such as Extended Spectrum Beta Lactamase (ESBL) and Methicillin Resistant Staphylococcus aureus (MRSA), therefore, irrational use of antibiotics worsens this condition. Bacterial resistance to antibiotics has become a serious global problem. Around 440 thousand new cases of MDR-TB (Tuberculosis-Multi-Drug Resistance) are reported every year, thereby causing 150 thousand deaths worldwide (WHO, 2014).

The use of natural ingredients as raw materials in drug development is increasingly demanded by the pharmaceutical industry community. Meanwhile, according to the World Health Organization (WHO) data, about $80 \%$ of the world's population uses herbal-based products (Djorjevic, 2017). Passion fruit (Passiflora edulis Sims.), a member of the Passifloraceae family, has more than 500 species (Duarte and Robert, 2015), it was originated from Brazil and has spread to other countries in Asia, Australia, Africa, India, South America, and the Caribbean. Furthermore, passion fruit has other variants which are identified by the color of the fruit (Singh and Debojyuti, 2013) such as yellow (P. edulis var. Flavicarpa), purple ( $P$. edulis var. Edulis), and orange $(P$.

\section{* Corresponding Author:}

Isnaeni

Department of Pharmaceutical Chemistry, Universitas

Airlangga, Mulyorejo, Surabaya 60115, Indonesia

Phone: (031) 8955989 Fax: (031) 5036779

e-mail: isnaeni@ff.unair.ac.id edulis var. Caerulea). Passion fruit contains phytochemical compounds of glycosides including flavonoids luteolin-6-C-chinovoside, luteolin-6-Cfucoside, cyanogenic glycosides passibiflorin, epipassibiflorin, passicapsin, passicoriacin, routinecipassicogen, epipassicogen epitetraphilin B, amygdalin, prunacin, triterpenoid glycosides, and salicylic glycosides. Other chemical compounds such as harman alkaloid b-carbolin, harmine, harmaline and harmalol, phenol, carotene, and g-lactone are also found in passion (Bernes et al., 2007). Therefore, passion fruit has high nutritional value with multimineral content such as magnesium and phosphorus, various vitamins, as well as high carbohydrate and water (Zibadi et al., 2020).

The Yellow passion fruit pulp extract has been investigated for its antibacterial activity against Streptococcus mutans, and its most effective concentration was $40 \%$ to $45 \%$. The fermentation filtrate (FF) of yellow passion fruit (P. edulis forma Flavicarpa sims.) fermented using de Man-Rogosa Sharpe Broth (MRS) media has been reported to have antibacterial activity against Staphylococcus spp., MRSA, and Escherichia coli ESBL. Previous studies related to the isolation of probiotic bacteria from purple passion fruit showed that passion fruit contains Probiotics Lactobacillus bulgaricus, and Lactobacillus heterohiochii which produces exopolysaccharides that inhibits the attachment of pathogenic bacteria (Zahro, 2014).

\section{Methods \\ Plant source and determination \\ The red passion fruits were freshly collected from the local farm in Sidoarjo, on May 2020. It plant was}


determined based on the taxonomy character of leaf, flower, fruit, and steam plant as well as identified as Passiflora edulis Sims. by Herbarium Malangensis, Universitas Negeri Malang.

\section{Preparation of fermentation media}

The MRS broth was prepared by dissolving $52.2 \mathrm{~g}$ of MRS broth powder into $1 \mathrm{~L}$ of purified water. Also, sterilization was performed by autoclaving for $15 \mathrm{~min}$ at $121^{\circ} \mathrm{C}$. Nutrient agar (NA) media was prepared by dissolving $20.0 \mathrm{~g}$ of the NA powder into $1 \mathrm{~L}$ of purified water, and it was further heated in boiling water with continuous stirring to completely dissolve all the powder, and a consistent yellowish liquid was achieved by pouring $10 \mathrm{~mL}$ of the mixture into a test tubes using syringe while it is still warm and in liquid form. The test tubes then need to be plugged with cotton and autoclaved for $15 \mathrm{~min}$ at $121^{\circ} \mathrm{C}$.

\section{Sample preparation, fermentation, and characterization}

The passion fruits were washed and dried before being divided into two parts and the $5 \mathrm{~g}$ of fruit pulps was weighed and put into $50 \mathrm{~mL}$ of MRS broth media to be fermented with a rotary shaker at $150 \mathrm{rpm}, 37^{\circ} \mathrm{C}$ for $24 \mathrm{~h}$. After $24 \mathrm{~h}$ of fermentation the fermentation broth was removed, centrifuged and the supernatant was collected for characterization.

\section{Determination of total plate count (TPC)}

The supernatant was then serially diluted $1: 10$ to $10^{7}$ using sterile normal saline solution. Each of the serial dilution was inoculated on the MRS agar (Oxoid, UK), and incubated at $37^{\circ} \mathrm{C}$ for $24 \mathrm{~h}$. Furthermore, cell growth was observed and the plating colonies were counted using a bacteria colony counter.

\section{Inoculum preparation}

The selected strain of bacteria was transferred aseptically to sterile saline water, vortexed and then the turbidity was measured using a spectrophotometer against the sterile saline water to obtain $25 \%$ turbidity or optical density of $25 \%$ transmittance (about $10^{9} \mathrm{CFU} / \mathrm{mL}$ of bacteria) at $580 \mathrm{~nm}$ (Safarini et al., 2020).

\section{Antibacterial activity test of ff red passion fruit pulp through MIC and MBC determination}

This research used agar dilution technique, in which the $\mathrm{FF}$ of red passion fruit pulp according to dilution $(50 \%, 25 \%, 12.5 \%, 6.25 \%)$ was added to agar, hence a seeding that matches the amount of dilution plus one seed was required. It was used as a control without adding FF of red passion fruit pulp, and one seed for positive control with Meropenem $(25 \mu \mathrm{L} / \mathrm{mL})$ and then incubated overnight at $37^{\circ} \mathrm{C}$. The lowest concentration of FF of red passion fruit pulp that inhibits bacterial growth is the MIC. Therefore, the minimum concentration of antibiotics that kills bacteria/minimum bactericidal concentration (MBC) is determined by planting bacteria in liquid seedlings which are used for MIC when there is no further growth in agar (Soleha, 2015).

\section{Results}

Red passion fruit ( $P$. edulis Sims.), known as sour passion fruit, is one of the species of passion fruit and belongs to the family of Passifloraceae. This species is unique and has two different performances namely purple skin (growing in subtropical and tropical highlands) and red skin (growing in lowland tropics) (Karsinah and Mansur, 2010). In this study, the red passion fruits (Fig. 1) from a local farm in Sidoarjo (East Java) were used.

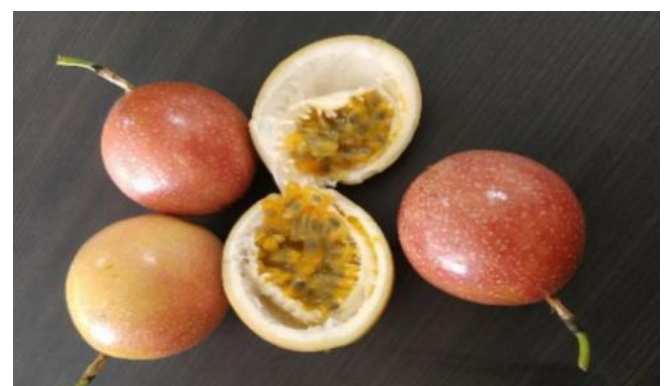

Figure 1. Red Passion Fruit (Passiflora edulis Sims).
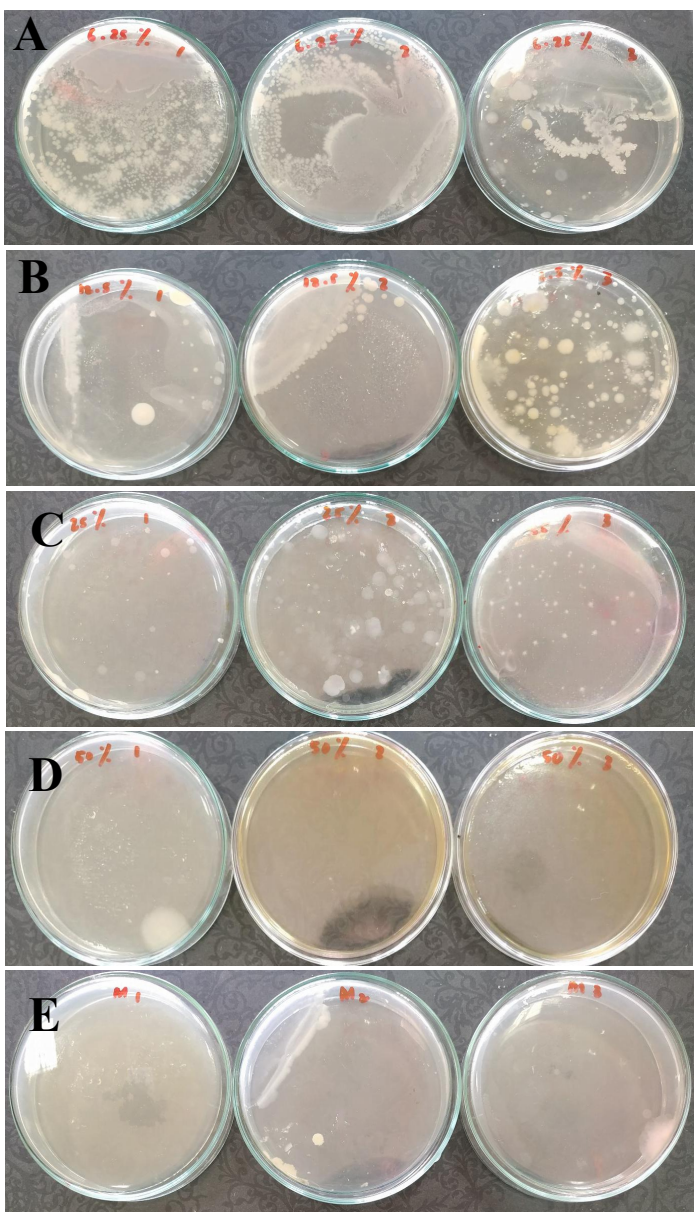

Figure 2. E. coli ESBL in the $6.25 \%$ Cell-Free Fermentation Supernatant (FF) of red passion fruit (Passiflora edulis Sims.) in de Man-Rogosa Sharpe agar (MRS-agar) Media, (a), E. coli ESBL in the $12.5 \% \mathrm{FF}$ of red passion fruit (b), E. coli ESBL in the $25 \% \mathrm{FF}$ of red passion fruit (c), E. coli $\mathrm{ESBL}$ in the $50 \% \mathrm{FF}$ of red passion fruit (d), E.coli $\mathrm{ESBL}$ with $25 \mu \mathrm{g} / \mathrm{mL}$ of meropenem (e) 
Based on the results of this research that has been investigated by $\mathrm{FF}$ of red passion fruit against $E$. coli ESBL and MRSA with MIC, the dilution concentration was $25 \%$, while minimum bactericidal concentration (MBC) was $50 \%$ dilution concentration. The FF of red passion fruit has been shown to inhibit the growth of $E$. coli ESBL and MRSA better than meropenem (Fig. 2 and Fig. 3), where at the MIC of meropenem MRSA growth was still visible.

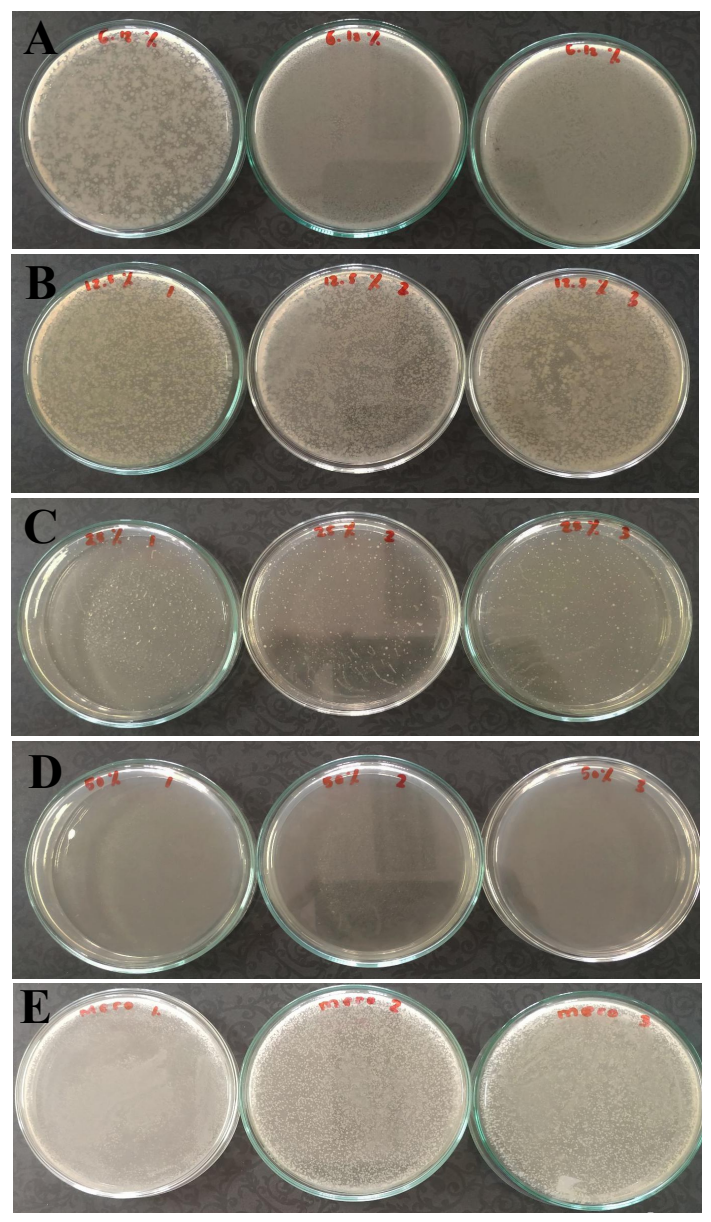

Figure 3. Methicillin-resistant Staphylococcus aureus (MRSA) in the $6.25 \%$ Cell-Free Fermentation Supernatant (FF) of red passion fruit (Passiflora edulis Sims.) in de Man-Rogosa Sharpe Agar (MRS-agar) Media (a), MRSA in the $12,5 \% \mathrm{FF}$ of red passion fruit (b), MRSA in the $25 \% \mathrm{FF}$ of red passion fruit (c), MRSA in the $50 \% \mathrm{FF}$ of red passion fruit (d), MRSA with $25 \mu \mathrm{g} / \mathrm{mL}$ of meropenem (e).

\section{Discussion}

$P$. edulis is a native fruit from Brazil, it has several common names, such as sour passion fruit, yellow passion fruit, black passion fruit, and purple passion fruit, and it presents a wide variability with the different rind colors of its fruits (Bernacci et al., 2008).Passion fruit has many health benefits because its nutritional content. Authentic passion fruit has a sour taste so it's rarely used directly and only made as a beverage ingredient. Though passion fruit is a raw material that produces good citric acid the good one since it contains citric acid in high concentration. The acidity of passion fruit citrate ranges from $2.4-4.8 \%$. Therefore, the citric acid is obtained by fermentation, and it is a weak organic acid found in the leaves and fruit of certain herbs. This compound is a good natural preservative that is used to regulate the acidity of various processed food and soft drink (Karsinah and Mansur, 2010). Therefore, this compound is thought to provide antibacterial activity from FF of red passion fruit against $E$. coli ESBL and MRSA.

In addition, red passion fruit contains probiotics (Nurrosyidah et al., 2020), which presumably also provide an antibacterial activity against $E$. coli ESBL and MRSA. Further studies related to the isolation of probiotic bacteria from purple passion fruit showed that passion fruit contains Probiotics Lactobacillus bulgaricus and Lactobacillus heterohiochii which produce exopolysaccharides that inhibits the attachment of pathogenic bacteria (Zahro, 2004). It is supported by the fermentation of probiotic bacteria from the fruit to produce organic acids that further strengthen its antibacterial activity against E. coli ESBL and MRSA, since the secondary metabolite content of red passion fruit has antibacterial potential.

In conclusion The MIC of red passion fruit fermentation filtrate against $E$. coli $\mathrm{ESBL}$ and MRSA was $25 \%$ dilution concentration, while MBC was $50 \%$ dilution concentration. This showed that red passion fruit has the potential to be developed as a candidate of antibacterial material, especially to overcome resistant bacteria.

\section{Acknowledgement}

This scientific paper was presented at the Third International I Conference on Agromedicine \& Tropical Diseases (ICATD) on September 12-13, 2020 at Jember University, Jember, East Java, Indonesia.

\section{References}

Barnes, J., Anderson, L., Phillipson, D., Zibadi, S., \& Ronald, R. W. (2007). Passion fruit Passiflora edulis. Evidence-Based Integrative Medicine, 1(3), 183-187.

Bernacci, L. S., Soares-Scott, M. D., Junqueira, N . T. V., Passos, I. R. D. S., \& Meletti, L. M. M. (2008). Passiflora edulis Sims: the correct taxonomic way to cite the yellow passion fruit (and of others colors). Revista Brasileira de fruticultura, 30(2), 566576 .

Djordjevic, S. M. (2017). From Medicinal Plant Raw Material to Herbal Remedies. IntechOpen, London.

Duarte, O., \& Robert, P. (2015). Exotic Fruits and Nuts of the New World. CABI, Lima.

Nurrosyidah, I. H., Isnaeni, I., \& Mertaniasih, N. M. (2020). Potential probiotic from indigenous Indonesian red passion fruit (Passiflora edulis Sims). Systematic Reviews in Pharmacy, 11(8), 123-130.

Sardjono, T. W., \& Le, F. (2007). Malaria, Mekanisme Terjadinya Penyakit Dan Pedoman Penanganannya. Malang: Parasite Laboratory of Faculty of Medicine, Universitas Brawijaya.

Safarini, M., Rosyidah, I. H., Mertaniasih, N. M., Hamzah, M. N. S. B., Novianti, K. A., Primaharinastiti, R., \& Isnaeni. (2020). In vitro antibacterial activity of cell free fermentation supernatant of Passiflora edulis form a flavicarpa Sims, fruit fermented by de man, rogosa and sharp media. Jordan Journal of Biological Sciences, 13(4), in press.

Singh, S., \& Debojyoti, D. (2013). Passion fruit: a fetched passion for dentists. International Journal of Pharmaceutical Sciences and Research, 4(2), 754-75

Soleha, T. U. (2015). Uji kepekaan terhadap antibiotik. Juke Unila, 5(9), 119-123. 
Surest, A. H., Redho, O., and Nabilla, M. A.. (2013). Fermentasi buah markisa (Passiflora) menjadi asam sitrat. Jurnal Teknik Kimia, 19(3), 1-7

World Health Organization. (2014). Antimicrobial Resistance: Global Report on Surveillance. Geneva: World Health Organization.
Zahro, F. (2014). Isolasi dan identifikasi bakteri asam laktat asal fermentasi markisa ungu (Passiflora edulis var. Sims) sebagai penghasil eksopolisakarida. Doctoral Dissertation in Faculty of Science and Technology, Universitas Islam Negeri Maulana Malik Ibrahim. 